\title{
Massive Subaponeurotic Haemorrhage in Infants Born by Vacuum Extraction
}

\author{
G. L. AHUJA,* M.B., B.S., D.C.H.; M. L. N. WILLOUGHBY, † M.A., M.D., M.C.PATH. \\ MARGARET M. KERR, $\ddagger$ M.D., M.R.C.P., D.C.H. ; J. H. HUTCHISON,§ M.D., F.R.C.P., F.R.S.ED.
}

British Medical fournal, 1969, 3, 743-745

\begin{abstract}
ummary : Nine out of 232 infants on whom the vacuum $\checkmark$ extractor was employed developed subaponeurotic haemorrhage and two of these infants died. In a further 78 infants born by vacuum extraction, all of whom received intramuscular vitamin $K_{1}$, four sustained subaponeurotic haemorrhage and one died. This type of haemorrhage was not encountered in over 12,000 infants born by other methods. Its relationship to vacuum extraction was found to be significantly more frequent when the thrombotest level was $10 \%$ or below of normal adult activity. It is suggested that infants born by vacuum extraction and with a thrombotest level of $10 \%$ or below might be protected from subaponeurotic haemorrhage by the transfusion of fresh frozen plasma.
\end{abstract}

\section{Introduction}

Descriptions of the caput succedaneum (a serosanguineous collection of fluid over the presenting part of the foetal skull) and of cephalhaematoma (a subperiosteal heamorrhage confined to the surface of a cranial bone by the suture lines) are to be found in every textbook of obstetrics or paediatrics. Neither condition is likely to inconvenience the infant seriously, and in cephalhaematoma both the extent and the rate of bleeding are limited by the firmly attached periosteum. On the other hand, haemorrhage under the epicranial aponeurosis and into the areolar tissues of the infant's scalp is rarely mentioned in standard textbooks, while both its extent and its rate can be disastrous in their severity. It has been our experience in recent years that subaponeurotic haemorrhage, sometimes fatal in its consequences, is particularly likely to be associated with the use of the vacuum extractor, and we hope that the following account may alert others to this danger.

* Registrar, Royal Hospital for Sick Children, Glasgow C.4. † Consultant Haematologist, Queen Mother's Hospital, Glasgow C.3. ‡Consultant Paediatrician, Queen Mother's Hospital, Glasgow C.3. $\checkmark$ Professor of Child Health, University of Glasgow.

\section{Case Material}

During the period from 1 February 1964 to 31 March 1967 6,439 infants were born in the Queen Mother's Hospital. In 232 cases the vacuum extractor was used, not always successfully, and nine infants suffered from subaponeurotic haemorrhage with two deaths (Table I). In four of these infants vacuum extraction was successful in completing the delivery, in two delivery had to be completed by caesarean section, and in three by mid-cavity forceps. The fatal outcome in Case 9 might have been prevented had a clearer appreciation of the size and rate of the haemorrhage led to earlier blood transfusion. This fatality prompted us to require that every infant born after use of the vacuum extractor should receive $2-5 \mathrm{mg}$. of phytomenadione (vitamin $\mathrm{K}_{1}$ ) by intramuscular injection shortly after birth. From 1 April 1967 to 15 May 1969, 6,209 infants have been born in the hospital. In 78 the vacuum extractor was employed and all received vitamin $K_{1}$. In three of these cases (one completed by forceps) slight subaponeurotic haemorrhage developed and in a fourth case (No. 13) massive fatal haemorrhage occurred. Blood transfusion was given in 4 of the 13 cases, including two of the three fatal cases (Table I).

\section{Fatal Cases}

Case 2.-A female baby weighing $3,870 \mathrm{~g}$. was born to a 27 -yearold primigravida 13 days after the expected date of delivery. Labour, induced by artificial rupture of the membranes, was prolonged owing to incoordinate uterine action. The first stage lasted 46 hours. After one hour in the second stage the head was in the occipitoposterior position when the patient was anaesthetized and the vacuum extractor applied. After some advance of the foetal head the suction cup came off. The head was then rotated to the occipitoanterior position and axis traction forceps were applied, but as moderate traction produced no advance disproportion was thought to be present and delivery was completed by lower segment caesarean section. The infant was limp and shocked with an Apgar score at two minutes of 1 . Resuscitation was satisfactorily achieved in hyperbaric oxygen. At the age of 90 minutes it was observed that there was pitting oedema over the left side of the scalp and also a

TABLE I.-Details of 13 Cases of Subaponeurotic Haemorrhage (Cases 10-13 after Prophylactic Vitamin $K_{1}$ )

\begin{tabular}{|c|c|c|c|c|c|c|c|c|c|c|c|c|c|c|c|c|c|}
\hline \multirow{2}{*}{$\begin{array}{l}\text { Case } \\
\text { No. }\end{array}$} & \multirow{2}{*}{ Sex } & \multirow{2}{*}{$\begin{array}{c}\text { Weight } \\
\text { (g.) }\end{array}$} & \multirow{2}{*}{\begin{tabular}{|l|} 
Maturity \\
(Weeks)
\end{tabular}} & \multirow{2}{*}{$\begin{array}{l}\text { Apgar } \\
\text { Score }\end{array}$} & \multirow{2}{*}{$\begin{array}{l}\text { Mode of } \\
\text { Delivery }\end{array}$} & \multirow{2}{*}{$\begin{array}{l}\text { Age of } \\
\text { Onset } \\
\text { (Hours) }\end{array}$} & \multicolumn{2}{|c|}{ Thrombotest } & \multicolumn{2}{|c|}{ Lowest $\mathrm{Hb}$} & \multirow{2}{*}{ Icterus } & \multicolumn{2}{|c|}{$\underset{\text { Bilirubin }}{\text { Maximum }}$} & \multicolumn{3}{|c|}{ Treatment } & \multirow{2}{*}{ Result } \\
\hline & & & & & & & $\begin{array}{c}\text { Age } \\
\text { (Hours) }\end{array}$ & $\%$ & $\begin{array}{c}\text { Age } \\
\text { (Hours) }\end{array}$ & $100 \mathrm{ml}$. & & $\begin{array}{c}\text { Age } \\
\text { (Days) }\end{array}$ & $\begin{array}{l}\mathrm{mg} . / \\
100 \mathrm{ml} .\end{array}$ & $\begin{array}{l}\mathrm{T} . \\
\mathrm{K}_{1}\end{array}$ & $\underset{\mathbf{K}}{\mathbf{P}}$ & Blood & \\
\hline$\frac{1}{2}$ & $\underset{F}{M}$ & $\begin{array}{l}3,390 \\
3,870\end{array}$ & $\begin{array}{l}40 \\
42\end{array}$ & $\begin{array}{l}4 \\
1\end{array}$ & $\begin{array}{l}\text { V.E., M.C.F. } \\
\text { V.E., M.C.F.F.; }\end{array}$ & 12 & 12 & $<5$ & 12 & 9 & $\bar{z}$ & $\overline{-}$ & $=$ & \pm & $=$ & \pm & $\begin{array}{l}\mathbf{R} \\
\mathbf{D}\end{array}$ \\
\hline $\begin{array}{l}3 \\
4 \\
5 \\
6 \\
7 \\
8\end{array}$ & $\begin{array}{c}M \\
M \\
M \\
F \\
M \\
F\end{array}$ & $\begin{array}{l}2,640 \\
3,710 \\
3,550 \\
2,880 \\
3,980 \\
3,600\end{array}$ & $\begin{array}{l}41 \\
41 \\
42 \\
37 \\
41 \\
40\end{array}$ & $\begin{array}{l}5 \\
8 \\
4 \\
9 \\
9 \\
7\end{array}$ & $\begin{array}{l}\text { V.E.O.C.S. } \\
\text { V.E. } \\
\text { V.E. } \\
\text { V.E., M.C.F. } \\
\text { V.E., M.C.F. } \\
\text { v.E., M.C.F., }\end{array}$ & $\begin{array}{r}16 \\
30 \\
1 \\
19 \\
4 \\
\frac{1}{2}\end{array}$ & $\begin{array}{l}16 \\
36 \\
22 \frac{1}{2} \\
\frac{22}{4}\end{array}$ & $\begin{array}{l}<5 \\
30 \\
10 \\
37 \\
12 \cdot 5\end{array}$ & $\begin{array}{l}16 \\
30 \\
24 \\
20 \\
\end{array}$ & $\begin{array}{r}9 \cdot 2 \\
16 \cdot 6 \\
12 \cdot 7 \\
16 \cdot 7 \\
=\end{array}$ & $\begin{array}{l}- \\
+ \\
+ \\
+ \\
+\end{array}$ & $\frac{\bar{z}}{\frac{4}{2}}$ & $\frac{}{\frac{22 \cdot 5}{9 \cdot 0}}$ & $\begin{array}{l} \pm \\
\pm \\
\pm \\
=\end{array}$ & $\begin{array}{l}\bar{z} \\
\bar{z} \\
\bar{z}\end{array}$ & $\begin{array}{l} \pm \\
= \\
=\end{array}$ & $\begin{array}{l}\mathbf{R} \\
\mathbf{R} \\
\mathbf{R} \\
\mathbf{R} \\
\mathbf{R} \\
\mathbf{R}\end{array}$ \\
\hline 9 & $M$ & 3,900 & 43 & 8 & v.E. & 8 & 13 & $<5$ & 13 & 13.5 & - & - & - & + & - & + & D \\
\hline $\begin{array}{l}10 \\
11 \\
12 \\
13\end{array}$ & $\begin{array}{c}M \\
M \\
F \\
M\end{array}$ & $\begin{array}{l}4,070 \\
3,540 \\
4,000 \\
3,210\end{array}$ & $\begin{array}{l}41 \\
39 \\
42 \\
40\end{array}$ & $\begin{array}{l}9 \\
2 \\
8 \\
8\end{array}$ & $\begin{array}{l}\text { V.E. } \\
\text { V.E., M.C.F. } \\
\text { V.E. } \\
\text { V.E., L.C.F. }\end{array}$ & $\begin{array}{c}13 \\
6 \\
5 \\
1 \frac{1}{2}\end{array}$ & $\overline{\frac{7}{2}}$ & $\begin{array}{l}\frac{7}{7} \\
<5\end{array}$ & $\begin{array}{r}1 \overline{44} \\
48 \\
3\end{array}$ & $\begin{array}{l}1 \overline{15.0} \\
15.2 \\
16.6\end{array}$ & $\begin{array}{l} \pm \\
\pm\end{array}$ & $\bar{z}$ & $\overline{7}$ & $\begin{array}{l}\bar{z} \\
\bar{z}\end{array}$ & $\begin{array}{l}+ \\
+ \\
+ \\
+\end{array}$ & $\overline{\bar{y}}$ & $\begin{array}{l}\mathrm{R} \\
\mathrm{R} \\
\mathrm{R} \\
\mathrm{D}\end{array}$ \\
\hline
\end{tabular}

$\mathrm{R}=$ Vec.E. $=$ Vacuum extractor. M.C.F. $=$ Mid-cavity forceps. L.C.F. $=$ Low cavity forceps. L.S.C.S. $=$ Lower segment caesarean section. $T=$ Died. 
fluctuant swelling over the right parietal area. At the age of 5 hours the infant rapidly deteriorated and died in a few minutes. Necropsy revealed massive haemorrhage into the areolar tissues of the scalp (estimated volume $150 \mathrm{ml}$.). The cerebellum also was covered in blood and bilateral tentorial tears were present. The lungs had completely expanded. The mother has since had two successful pregnancies.

Case 9.-A male baby weighing 3,900 g. was born to a 19 -yearold gravida-1 17 days after the expected date of delivery. Labour started spontaneously. The first stage lasted five hours. Delivery was easily effected with the vacuum extractor, applied because of foetal bradycardia. The Apgar score at two minutes was 8 . At the age of 8 hours the infant become pale and lethargic and considerable oedema of the scalp was noted. The heart rate was 120/ min. and the haemoglobin was $14.7 \mathrm{~g} . / 100 \mathrm{ml}$. By the age of 13 hours the heart rate was $140 / \mathrm{min}$. and the haemoglobin $13.5 \mathrm{~g}$./ $100 \mathrm{ml}$. Gross pitting oedema of the scalp was present. The infant was given $5 \mathrm{mg}$. of phytomenadione intramuscularly (thrombotest activity $<5 \%$ of adult normal), and cross-matching of blood was instituted. Forty-five minutes later, however, the infant's condition suddenly deteriorated and transfusion was started via an umbilical vein catheter with "screened" $\mathrm{O} R \mathrm{Rh}$-negative blood. There was no improvement, and the infant died after $70 \mathrm{ml}$. had been transfused along with $5 \mathrm{mEq}$ of sodium bicarbonate. Necropsy revealed a massive subaponeurotic haemorrhage which had raised the entire scalp. The volume was estimated as at least $100 \mathrm{ml}$. The mother has since had a healthy baby who showed no clinical evidence of a haemorrhagic tendency. It is of interest that her firstborn child suffered from mild haemorrhagic disease of the newborn.

Case 13.-A male infant weighing $3,210 \mathrm{~g}$. was born to a 28 year-old primigravida at term. Mild pre-eclamptic toxaemia had been present from the 36 th week. The membranes ruptured spontaneously. After 24 hours in labour the mother was distressed and feverish, and though a rim of cervix presented it was decided to attempt vaginal delivery. The foetal head was brought down to the perincum by the vacuum extractor, the delivery being completed with axis traction forceps. The Apgar score at two minutes was 8 . The infant's head showed considerable moulding. Phytomenadione $5 \mathrm{mg}$. was injected at 75 minutes, when the infant seemed healthy. At two hours considerable oedema of the scalp was noted and the thrombotest activity was less than $5 \%$. Blood grouping and cross-matching were immediately put in hand. At 3 hours the haemoglobin was $16.6 \mathrm{~g} . / 100 \mathrm{ml}$. and the heart rate $160 / \mathrm{min}$. The umbilical vein was catheterized at $3 \frac{1}{2}$ hours and the infant collapsed. In spite of $70 \mathrm{ml}$. of blood and $20 \mathrm{mEq}$ of intravenous sodium bicarbonate, plus tracheal intubation and intermittent positive-pressure ventilation, the infant failed to regain consciousness and died aged $7 \frac{1}{2}$ hours. Necropsy revealed only massive subaponeurotic haemorrhage.

\section{Clinical Features}

Infants born by vacuum extraction usually show a pronounced artificial caput or "chignon," which rapidly subsides, leaving a normal caput succedaneum with a circular area of ecchymosis. Subaponeurotic haemorrhage is indicated by a later diffuse swelling of the scalp, which can be made to pit on pressure. In some infants there is also a fluctuant "fluid" swelling clearly distinguishable from oedema and usually situated over the occipital region. In severe cases the whole scalp above the ears feels tight and raised. Bluish-black bruising may appear in the frontal or suboccipital areas. The haemoglobin level sometimes falls to a low figure, but in our fatal cases the haemoglobin did not reflect the severity of the haemorrhage, presumably because the bleeding was so rapid that there was insufficient time for haemodilution and reconstitution of the plasma volume. The signs of haemorrhage may appear as soon as $1 \frac{1}{2}$ hours and as late as 48 hours after birth. The breakdown of haemoglobin retained in the tissues may result in hyperbilirubinaemia (Rausen and Diamond, 1961), and jaundice developed in 6 of our 10 survivors. Robinson and Rossiter (1968) devised a formula for assessing the amount of blood loss, based on a comparison between the actual and the expected head circumference of the infant. In our experience the presence of moulding and the caput succedaneum make such measurements of doubtful validity in the hours immediately after birth.

\section{Tests of the Clotting Mechanism}

The thrombotest has been used by us in preference to Quick's one-stage prothrombin time since it measures specifically those coagulation factors which are vitamin-K-dependent and are synthesized in the liver-namely, factors VII, IX, and X and prothrombin. These are the factors which are normally reduced in the neonatal period and which are excessively reduced in haemorrhagic disease of the newborn. The low level of factor IX (Christmas factor) is probably more closely related to overt bleeding than are low levels of the other factors (Aballi et al., 1959). Quick's prothrombin time is less suitable for assessing these factors, as it partially reflects the levels of certain other irrelevant factors ( $\mathrm{V}$ and fibrinogen) while being totally insensitive to variations in factor IX. A further practical advantage in using the thrombotest is that it can readily be performed on capillary heel-stab blood samples, obviating the need for venepuncture. Recently the thrombotest has been used in the study of infants of low birth weight by Gray et al. (1968). They found an increased incidence of intracranial haemorrhage when this level was below $10 \%$ of normal adult activity.

Table II shows the thrombotest results during the first 36 hours of life in 251 babies born by spontaneous vertex delivery (96), forceps delivery (74), vacuum extraction (38), caesarean section (28), and breech delivery (15). In about one-quarter of these infants the thrombotest activity was $10 \%$ or less, and in one-half of this group it was less than $5 \%$ of normal. These low levels represent a serious degree of coagulation deficiency by adult standards but show the usual variation encountered in the newborn.

\begin{tabular}{|c|c|c|c|c|c|c|c|c|c|c|}
\hline $\begin{array}{l}\text { Thrombotest levels } \\
\text { No. of infants } \quad .\end{array}$ & $\begin{array}{l}<5 \\
30\end{array}$ & ${ }^{5-}$ & $\begin{array}{r}11- \\
42\end{array}$ & $\begin{array}{r}16- \\
42\end{array}$ & $\begin{array}{r}21- \\
38\end{array}$ & $\begin{array}{r}26- \\
24\end{array}$ & ${ }^{31} 15$ & $\begin{array}{r}36- \\
14\end{array}$ & $41-$ & $\begin{array}{c}>45 \\
4\end{array}$ \\
\hline
\end{tabular}

Table III shows the separate thrombotest results in 38 babies delivered by vacuum extraction and the relationship of these results to the occurrence of subaponeurotic haemorrhage. This type of haemorrhage is seen to be significantly more frequent when the thrombotest is at or below $10 \%$ than when it is above this level. When this relationship is tested by means of contingency tables the correlation is significant at the $1 \%$ level of probability $\left(\chi^{2}=6 \cdot 72, P<0 \cdot 01\right)$. TABLE III.-Results of Thrombotest in 38 Infants Delivered by Vacuum
Extractor (Percentages of Adult Normal)
\begin{tabular}{c|c|c|c|c|c|c|c|c|c|c}
$\begin{array}{c}\text { Thrombotest levels } \\
\text { No. of infants with: } \\
\text { Subaponeurotic } \\
\text { haemorrhage }\end{array}$ & $<5$ & $5-$ & $11-$ & $16-$ & $21-$ & $26-$ & $31-$ & $36-$ & $41-$ & $>45$ \\
No haemorrhage & 2 & 2 & 1 & 0 & 0 & 1 & 0 & 1 & 0 & 0 \\
\hline
\end{tabular}

\section{Discussion}

Massive subaponeurotic haemorrhage in the newborn is to be regarded as an uncommon form of haemorrhagic disease of the newborn. In 37 of the 51 cases described in the literature consulted (Aballí et al., 1959 ; Leonard and Anthony, 1961 ; Pachman, 1962 ; Van der Horst, 1963 ; Kozinn et al., 1964 ; Lang, 1964 ; Malmström, 1964 ; Valentine, 1964 ; Barrow and Peters, 1968 ; Robinson and Rossiter, 1968) the affected infants were of African or non-Caucasian origin. In only nine of them was the vacuum extractor involved. On the other hand, there 
is evidence that haemorrhagic disease is several times commoner in African than in white infants (Lanzkowsky et al., 1967). All our 13 cases were in white infants, and in each one the vacuum extractor had been used. No cases of subaponeurotic haemorrhage have been seen in our hospital in over 12,000 deliveries by other methods. It is well recognized that the incidence of haemorrhagic disease of the newborn does not correlate closely with the prothrombin time. Other factors, such as trauma, or temporary hepatic insufficiency from hypoxia, infection, or immaturity, play a part.

While the relationship of subaponeurotic haemorrhage to vacuum extractor in our hospital can leave little room for doubt that the trauma inflicted on the soft tissues of the foetal scalp is an important aetiological factor, the fact that in seven of the nine cases in which it was measured the thrombotest activity was less than $15 \%$ indicates the even greater influence of the blood-clotting mechanism. Indeed, it is clear that delivery by vacuum extraction when associated with a thrombotest activity below $10 \%$ constitutes a grave risk of fatal or dangerous haemorrhage in the baby. It was a disappointment to us that the routine administration of phytomenadione by intramuscular injection to every infant born by vacuum extractor did not abolish subaponeurotic haemorrhage, or in fact prevent fatal haemorrhage, in one infant. As paediatricians we are not competent to pronounce on the merits of delivery by vacuum extractor in contrast to other instrumental methods, and several experienced obstetricians have written enthusiastically on its use (Malmström, 1964 ; Willocks, 1962 ; Chalmers, 1964).

We think it appropriate, however, to present the undesirable effects which we have encountered. We now believe that, if possible, the thrombotest should be performed as soon after birth as possible in every infant on whom the vacuum extractor has been used. As our experience indicates that the action of vitamin $K_{1}$ is not rapid enough to prevent massive bleeding consideration might be given to the transfusion of fresh frozen plasma, $10 \mathrm{ml} . / \mathrm{kg}$., in every infant born by vacuum extraction and with a thrombotest activity at or below $10 \%$. This policy has already been shown to lessen the risk of death from intracranial haemorrhage in infants of low birth weight with low thrombotest levels (Gray et al., 1968).

\section{REFERENCES}

Aballí, A. J., Banús, V. L., de Lamerens, S., and Rozengvaig, S. (1959).

American fournal of Diseases of Children, 97, 524.
Barrow, E., and Peters, R. L. (1968). South African Medical fournal, 42, 265.

Chalmers, J. A. (1964). British Medical fournal, 1, 1216.

Gray, O. P., Ackerman, A., and Fraser, A. J. (1968). Lancet, 1, 545. American fournal of Diseases of Children, 108, 413 .

Lange, P. (1964). Acta Obstetrica et Gynecologica Scandinavica, 43, Supplement No. 1 , p. 53.

Lanzkowsky, P., Joffe, H. S., Levy, S., Nossel, H. L., and Mibashan, R. S. (1967). South African Medical fournal, 41, 1039

Leonard, S., and Anthony, B. (1961). American fournal of Diseases of Children, 101, 170 .

Malmström, T. (1964). Acta Obstetrica et Gynecologica Scandinavica, 43, Supplement No. 1 , p. 5.

Pachman, D. J. (1962). Pediatrics, 29, 907.

Rausen, A. R., and Diamond, L. K. (1961). American fournal of Diseases of Children, 101, 164 .

Robinson, R. J., and Rossiter, M. A. (1968). Archives of Diseases in Childhood, 43, 684 .

Valentine, G. H. (1964). Canadian Medical Association fournal, 91, 177. Van der Horst, R. L. (1963). Archives of Diseases in Childhood, 38, 280.

Willorks, J. (1962). Fournal of Obstetrics and Gynaecology af the British Commonwealth, 69, 266.

\title{
Comparison of Birth Weight/Gestation Distribution in Cases of Stillbirth and Neonatal Death According to Lesions Found at Necropsy
}

\author{
JEAN FEDRICK,* M.A.
}

British Medical fournal, 1969, 3, 745-748

\begin{abstract}
Summary : The birth weight/gestation distribution of a $\checkmark$ large series of cases of perinatal death has been analysed according to the lesion (or lesions) present at necropsy. Among the lesions associated with low gestation babies dying with hyaline membranes have a much higher mean birth weight for gestation than either the babies with intraventricular haemorrhage or " no cause found." Among infants dying of intrapartum asphyxia or cerebral birth trauma it was found that those who were stillborn with trauma had, at term, a significantly higher mean birth weight than the control livebirths, and that, at all gestations, the stillbirths with trauma were, on average, heavier than the babies dying neonatally with this lesion. Cases of intrapartum asphyxia were smaller than the stillbirths with trauma, but those dying during the second stage of labour were larger than those dying during the first stage.
\end{abstract}

Cases of intrauterine pneumonia-that is, stillbirths and first-day deaths-were also shown to be larger for length of gestation than cases of extrauterine pneumonia-that

* Honorary Research Assistant, Department of Human Genetics and Biometry, University College London, London W.C.1. is, deaths between the second and the 28th day. The cases with haemorrhagic pneumonia, however, were, at least at term, smaller than the cases of extrauterine pneumonia, and cases of massive pulmonary haemorrhage showed evidence of growth retardation at all gestations.

\section{Introduction}

Though many authors have studied the birth weights or, more rarely, the periods of gestation of a series of cases in which perinatal death occurred, only occasionally has the combination of birth weight with gestation been examined. As this is a valuable indication of whether the foetus or infant concerned was in "distress" before the actual processes of labour and delivery began (Gruenwald, 1963), the unique data of the British Perinatal Mortality Survey have been analysed with regard to certain lesions found at necropsy.

\section{Material and Methods}

The data used are those of the 7,117 singleton stillbinths and neonatal deaths occurring in March, April, and May 1958 